\title{
PEMIKIRAN EKONOMI ISLAM KONTEMPORER
}

\section{Nela Novyanti 90100118098}

\section{Email : naynovy23@gmail.com}

Pemikiran ekonomi Islam muncul bersamaan dengan diturunkannya AlQur'an dan masa kehidupan Rasulullah yakni pada akhir abad $6 \mathrm{M}$ hingga awal abad 7 M. Pelaksanaan sistem ekonomi Islam telah ada dan dilaksanakan oleh Rasulullah SAW sebagai seorang Rasul tauladan bagiumat muslim. Bahkan bangsa Arab telah terkenal sebagai bangsa pedagang sebelum periode Rasulullah SAW (Fauzi, et al., 2019). Namun Kemudian barulah mulai didokumentasikan kurang lebih sejak tiga abad semenjak wafatnya Nabi Muhammad Saw. Beberapa pemikir yang cukup terkenal antara lain : Abu Yusuf (731-798), Yahya ibn Adham (818), El-Hariri (1054-1122), Tusi (1201-1274), Ibn Taimiyah (12621328), Ibn Khaldun (1332-1406) dan Shah Waliullah (1702-1763) (Khoir, 2010). Pemikiran-pemikiran dari cendekia-wan muslim tentang ekonomi islam ini sempat berhenti beberapa abad lamanya. Pertengahan abad ke-20 M pemikiran ekonomi Islam berkembang kembali (Nurrohman \& Nurhaeti, 2019). Dengan muncul pemikir-pemikir ekonomi kontemporer yang dapat dikategorikan dalam tiga kelompok mazhab pemikiran yaitu (Maulidizen, 2017) :

1. Mazhab Baqir As-Sadr

Pada aliran ini pemikiran tentang pemecahan masalah ekonomi yang muncul disebabkan distribusi yang tidak merata dan adil sebagai pengaruh dari ekonomi kapitalis yang menguntungkan pihak yang kuat dan kaya sehingga terjadilah ketimpangan sosial menyebabkan maraknya kasus eksploitasi, diskriminasi, monopoli, dan alienasi. Perebutan kepemilikan harta kekayaan alam terus berlangsung berkecamuk disegalah lini yang berujung pada kriminalitas dan konflik sosial, yang sangat sulit untuk dihindari (Sirajuddin \& Tamsir, 2019). Pemahaman ekonomi iqtisaduna beranggapan bahwa puncak permasalahan ekonomi adalah bukan karena sumber daya yang tidak terbatas, tetapi karena 
ketamakan manusia yang tidak terbatas. Faham mazhab ekonomi ini menganggap bahwa segala sumber daya alam adalah tidak terbatas. Aliran ini dipelopori oleh Baqir Sadr. Membahas mengenai permintaan dan penawaran, hubungan antara keuntungan dan bunga, juga fenomena diminishing return dalam suatu produksi.

\section{Mazhab Mainstream}

Sebagai kebalikan dari aliran iqtisaduna. Mazhab ini Pmengemukakan bahwa permasalahan ekonomi, menurut mereka masalah ekonomi dikarenakan kekurangan (scarcity). Ini maksudnya segala sumber daya alam adalah terbatas tetapi keperluan manusia yang tidak terbatas. Untuk itu manusia diarahkan untuk melalukan aktivitas ekonomi berdasarkan kepada skala prioritas dalam memenuhi kebutuhan manusia dengan tetap berpegang teguh kepada al-Qur"an dan alHadist. Tokoh-tokoh utama pada aliran ini iaitu, Muhammad abdul Mannan, Muhammad Nejatullah Siddiqi, Syed Nawab Haidar Naqvi, dan Monzer Kahf.

\section{Mazhab Alternatif}

Aliran ini adalah aliran kritis secara ilmiah terhadap ekonomi Islam, baik sebagai ilmu maupun sebagai peradaban. Aliran ini mengkritik kedua aliran kontemporer sebelumnya. Aliran Iqtiṣādunā dikritik karena dianggap berusaha mengemukakan sesuatu yang baru yang sebenarnya sudah ditemukan oleh tokohtokoh klasik sebelumnya, sedangkan aliran mainstream dikritik sebagai aliran serapan dari neo-klasik tetapi mengahapuskan elemen ribā serta menambah zakat dan akad, sehingga tidak ada keaslian pada aliran ini. Tokoh aliran ini adalah Timur Kuran.

Beragamnya pemikiran mengenai ekonomi Islam dasarnya merupakan ijtihād para cendikiawan Muslim dalam membentuk kerangka ekonomi yang patuh Syariah. Walaupun banyak perbedaan, tetapi mereka tetap merujuk kepada al-Qurean dan al-Hadīth sebagai sumber ilmu yang absolut. Akhirnya, atas sumbangan pemikiran merekalah kontruksi bangunan sistem ekonomi Islam akan mampu menghantarkan seluruh manusia kepada kesejahteraan dan keadilan sosial yang merata. (Maulidizen, 2017) 


\section{DAFTAR PUSTAKA}

Helim, A., \& Fauzi, I. (2019). Sejarah pemikiran ekonomi islam (Masa Rasulullah sampai masa kontemporer).

Khoir, M. (2010). Pemikiran Dan Mazhab Ekonomi Islam Kontemporer. BALANCE: Economic, Business, Management and Accounting Journal, 7(01).

Maulidizen, A. (2017). Pemikiran Dan Kontribusi Tokoh Ekonomi Islam Klasik Dan Kontemporer. deliberatif, 1(1), 42-62.

Nurohman, N. (2019). Pemikiran Ekonomi Mikro Islam Dalam Lintasan Sejarah. Aksy: Jurnal Ilmu Akuntansi dan Bisnis Syariah, 1(2), 225-232.

Sirajuddin, S., \& Tamsir, T. (2019). Rekonstruksi Konseptual Kepemilikan Harta Perspektif Ekonomi Islam (Studi Kritis Kepemilikan Harta Sistem Ekonomi Kapitalisme). Laa Maisyir: Jurnal Ekonomi Islam, 6(2), 211-225. 